\title{
MANAGEMENT PLACENTA PERCRETA SUCCESFULLY WITH TOTAL ABDOMINAL HYSTERECTOMY A CASE REVIEW :
}

\author{
Rajuddin Rajuddin ${ }^{1}$, Roziana ${ }^{1}$, Munawar ${ }^{1}$, Muhammad Iqbal ${ }^{2}$ \\ ${ }^{1}$ Department of Obstetrics \& Gynecology, Syiah Kuala University \\ ${ }^{2}$ Resident of Obstetrics \& Gynecology, Syiah Kuala University
}

Corresponding Author : iqbal_dctr@yahoo.com

\begin{abstract}
Background: Placenta accreta spectrum is one of the most serious complications of placenta previa and is frequently associated with severe obstetric hemorrhage usually necessitating hysterectomy. The management of placenta accrete spectrum will be discussed here and is essentially the same. The following discussion of management of placenta accreta spectrum applies to all depths of placental invasion. Incidence: In 1950 placentaaccreta was rare, occurring 1 in 30.000 deliveries in the United States. Duringbetween 2008 and 2011 in a cohort of over 115.000 deliveries in 25 hospitals in the United States reaching 1 in 731 deliveries. The marked increase has been attributed to the increasing prevalence of cesarean delivery in recent decades. The incidence of placenta accreta spectrum will also increase due to increasing of caesarean section rate. Case: Mrs.44 yo, G3P2 36-37weekslive, previous cesarean section 2 time,placenta previa totalis, placenta percreta. She's comes with a chief complaint of lower abdominal cramps, patients regularly antenatal care at obstetrician. Ultrasound finding, a single fetus lives at transvers lie, dorso superior, corresponding to 3637 weeks, placenta previa, placenta percreta (PAI:83\%). This patient planned for elective conservative surgery management, due to cesarean section and or cesarean hysterectomy. Discussion:Surgical conservative management giving birth a baby without a placenta, followed by a hysterectomy, has been shown to reduce the risk of bleeding and the need for blood transfusion. The discovery of placenta accreta spectrum earlier when antenatal care, better birth planning than multidisciplinary science includedfetomaternal, gyneco-oncologist, anesthesiologist, thorac\& cardiovascular surgeon, radiology intervention, intensivist obstetric intensive care, urologist and neonatology can determine the success of handling cases of placenta accreta spectrum so as to reduce maternal, fetal morbidity and mortality. Conclusions: The discovery of placenta accreta spectrum earlier when antenatal care, planning delivery is better than multidisciplinary science. Management with corporal incisions away from placental implantation, giving birth baby without a placenta, followed by a hysterectomy, has been shown to reduce the risk of bleeding and the need for blood transfusion.
\end{abstract}

Keyword : placenta previa, placenta accreta spectrum, increta, percreta and adhesiva 


\title{
Manajemen Placenta Percreta dengan Hysterectomy Total Abdominal : Study Kasus
}

\begin{abstract}
Abstrak
Latar Belakang: Spektrum plasenta akreta adalah salah satu komplikasi plasenta previa yang paling serius dan sering dikaitkan dengan perdarahan obstetrik parah yang biasanya memerlukan histerektomi. Pengelolaan spektrum akresi plasenta akan dibahas di sini dan pada dasarnya sama. Pembahasan manajemen spektrum plasenta akreta berikut ini berlaku untuk semua kedalaman invasi plasenta. Insidensi: Pada tahun 1950 plasentaaccreta jarang terjadi, terjadi 1 dari 30.000 pengiriman di Amerika Serikat. Selama antara 2008 dan 2011 dalam kelompok lebih dari 115.000 pengiriman di 25 rumah sakit di Amerika Serikat mencapai 1 dari 731 pengiriman. Peningkatan yang ditandai telah dikaitkan dengan meningkatnya prevalensi kelahiran sesar dalam beberapa dekade terakhir. Insiden spektrum plasenta akreta juga akan meningkat karena peningkatan tingkat operasi caesar. Kasus: Mrs.44 yo, G3P2 36-37weekslive, sebelumnya seksio sesarea 2 kali, plasenta previa totalis, plasenta percreta. Dia datang dengan keluhan utama kram perut bagian bawah, pasien secara teratur melakukan pemeriksaan kehamilan di dokter kandungan. Temuan USG, janin tunggal hidup di transvers kebohongan, lebih tinggi, sesuai dengan 36-37 minggu, plasenta previa, plasenta percreta (PAI: 83\%). Pasien ini merencanakan untuk manajemen operasi konservatif elektif, karena operasi caesar dan atau operasi caesar. Diskusi:Manajemen konservatif bedah melahirkan bayi tanpa plasenta, diikuti dengan histerektomi, telah terbukti mengurangi risiko perdarahan dan kebutuhan transfusi darah. Penemuan spektrum plasenta akreta lebih awal ketika perawatan antenatal, perencanaan kelahiran yang lebih baik daripada ilmu multidisiplin termasuk ibu, ginekolog, ahli anestesi, ahli bedah dada \& kardiovaskular, intervensi radiologi, intensivist - perawatan intensif obstetrik, urolog dan neonatologi dapat menentukan keberhasilan penanganan kasus plasenta Spektrum akreta sehingga mengurangi morbiditas dan mortalitas ibu, janin. Kesimpulan: Penemuan spektrum plasenta akreta lebih awal ketika perawatan antenatal, merencanakan persalinan lebih baik daripada ilmu multidisiplin. Manajemen dengan sayatan badan jauh dari implantasi plasenta, melahirkan bayi tanpa plasenta, diikuti dengan histerektomi, telah terbukti mengurangi risiko perdarahan dan kebutuhan untuk transfusi darah.
\end{abstract}

Kata kunci : plasenta previa, spektrum plasenta akreta, increta, percreta, dan adhesiva 


\section{INTRODUCTION}

Management of patients with placenta accreta spectrum (placenta accreta, increta, or percreta) varies widely in the United States ${ }^{[1]}$. Although the impact of placenta accreta spectrum on pregnancy outcomes is well described, no randomized trials and few studies have examined the management of pregnancies complicated by this disorder. As a result, recommendations for its management are based on case series and reports, personal experience, expert opinion, and good clinical judgment. The management of placenta accreta, increta, and percreta will be discussed here and is essentially the same, except when a percreta extends to extrauterine tissue. Unless otherwise noted, the following discussion of management of placenta accreta spectrum applies to all depths of placental invasion. The clinical features and diagnosis of placenta accreta spectrum are reviewed separately ${ }^{[2]}$.

Incidence placenta accreta is much more common than placenta increta and percreta. In a pooled analysis of results from two series involving a total of 138 histologically confirmed, abnormally implanted placentas from hysterectomy specimens, the types and frequencies of abnormal placentation were ${ }^{[3,4]}$ : Placenta accreta79\%, Placenta increta14\%, Placenta percreta 7\%. In 1950, placenta accreta was rare, occurring in 1 in 30,000 deliveries in the United States $^{[5,7]}$. During the $1980 \mathrm{~s}$ and $1990 \mathrm{~s}$, the incidence markedly increased, reaching 1 in 731 deliveries between 2008 and 2011 in a cohort of over 115,000 deliveries in 25 hospitals in the $\mathrm{US}^{[5,6]}$. The marked increase has been attributed to the increasing prevalence of cesarean delivery in recent decades ${ }^{[8]}$.

Clinically, the placenta becomes a problem during labor when the placenta is not completely separated from the uterus and is followed by massive obstetric hemorrhage, causing DIC, hysterectomy, repair of ureteric, bladder, intestinal or neurovascular structures, adult respiratory distress syndrome, transfusion reactions, electrolyte imbalance, and kidney failure $^{[10]}$. Maternal deaths with placenta percreta were reported to be as high as $20 \%$ and the average perinatal mortality was 30\%. Maternal death can occur despite optimal planning, transfusion management, and surgical treatment. Placenta percreta causes $7 \%-10 \%$ of cases of maternal death in the world ${ }^{[11]}$.

Management by a multidisciplinary team and delivery in a tertiary care facility improve outcomes and lower complication rates ${ }^{[17,18]}$. We schedule a multidisciplinary conference with all the key care participants at least two weeks prior to planned delivery to ensure that all necessary preparations are completed and management plans implemented ${ }^{[18]}$.

The multidisciplinary team includes maternal-fetal medicine specialists, anesthesiologists, neonatologists, interventional radiologists, and blood bank and nursing personnel. It is desirable to have a surgeon in the operating room who has extensive experience with wide dissection of the parametrium and exploration of the retroperitoneum in the event this expertise is required for control of bleeding, bladder resection, and/or isolation, partial resection, and/or reimplantation of the ureters. Some obstetrician gynecologists have this experience, general surgeons, urologists, and vascular surgeons also have expertise in this area. A urogynecologist, urologist, or gynecologic oncologist should be consulted in cases where there is expected bladder involvement or if the surgeon does not have the requisite surgical expertise ${ }^{[17]}$.

If an appropriate multidisciplinary team and support services are not available at the site the patient plans delivery, she should be transferred to a tertiary facility that has the capability to 
most effectively manage major intraoperative hemorrhage and provide postoperative intensive care ${ }^{[17,18]}$.

\section{CASE REPORT}

The 44-year-old woman claimed to be pregnant with her third child with a gestational age of 36-37 weeks. There was no previous history of abortion. Patients sent by obstetrician comes with chief complaints of abdominal cramps from 1 day before admission to hospital, contractions, blood slime and water broke was denied. The history of bloody and spotting at the beginning of pregnancy is also denied by the patient. And patients still felt the fetal movement until now. Patients antenatal care at the obstetrician 5 times and never to midwife, the last control on August 62018 doctor said the fetal was good condition, but the placenta covered the birth canal, doctors also say that the placenta is likely to penetrated to the uterine muscle. So that the patient was planned for elective cesarean section on August 8, 2018. The patient's history of vaginal discharge was recognized, but not itchy and odorless. Micturitions and defecations was in normal limits. History of asthma bronchiale, hypertension, diabetes mellitus, and heart disease in patients and families is denied. Based on history, patient's was menarche at 12 years of age, regular cycle, with a period of 6-7 days without dysmenorrhea. Birth history is 2 times with details: first child aged 15 years, male, birth weight $4800 \mathrm{~g}$, aterm, cesarean sections due to macrosomia at Meuraxa Hospital Banda Aceh, and the second child was 13 years old, male, birth weight $4500 \mathrm{~g}$, aterm, cesarean sections due to previous cesarean sections 1 time, macrosomia at Harapan Bunda Hospital Banda Aceh. This is currently the 3 rd pregnant.

Physical examination was found that the general condition of the patient was good with awareness of compos mentis, blood pressure $120 / 80 \mathrm{mmHg}$, pulse $80 \mathrm{x} /$ minute, breathing 22 $\mathrm{x} /$ minute, temperature $36.6 \mathrm{C}$, BMI $25 \mathrm{~kg} / \mathrm{m}^{2}$. Generalized status within normal limits. Obstetric states in patients was obtained by fundal height $27 \mathrm{~cm}$, head at left side, dorso superior, no contraction, fetal heart rate $150 \mathrm{x} /$ minute, genitalia inspection found vulva and urethra within normal limits, inspeculo examination found smooth postio, ostium uteri closed, negative fluxus, positive fluor albus, negative valsava and negative nitrazine test. vaginal touché examination is not performed.

Blood count laboratory on August $7^{\text {th }} 2018$ obtained hemoglobin $11.1 \mathrm{~g} / \mathrm{dl}$; hematocrit $33 \%$; leococyte $8.900 \mathrm{ul} / \mathrm{m}^{3}$; platelets $322.000 \mathrm{ul} / \mathrm{m}^{3}$; random blood glucous $106 \mathrm{gr} / \mathrm{dl}$; ALT $56 \mathrm{mg} / \mathrm{dl}$; AST $48 \mathrm{mg} / \mathrm{dl}$; ureum $11 \mathrm{mg} / \mathrm{dl}$; creatinine $0.50 \mathrm{mg} / \mathrm{dl}$. The impression is within normal limits. Cardiotocographic examination was obtained with reassuring of fetas state with a baseline of $145 \mathrm{x} /$ minute.

From the ultrasound examination on August $07^{\text {th }} 2018$, a single fetus, fetal heart rate positive, transvers lie dorso superior. The implantation of placenta on the anterior corpus extends to covered ostium uteri internum, maturation grade 1, lacunae appears grade 1, clear zone was negative, bridging vessel positive, myometrial thickness $0.7 \mathrm{~mm}$, PAI score 6 correlated with the possibility of placenta accrete $83 \%$. Fetal biometry; BPD $95 \mathrm{~mm}$, HC $322.6 \mathrm{~mm}$, AC $338 \mathrm{~mm}$, FL $75 \mathrm{~mm}$, AFI $3 \mathrm{~cm}$ single deepest pocket, estimated fetal weight 3538 gr. Conclusion single fetus live transvers lie, head at live side, dorso superior $\sim$ gestational age 36-37 weeks, placenta previa totalis, placenta percreta (PAI $8=83 \%$ ).
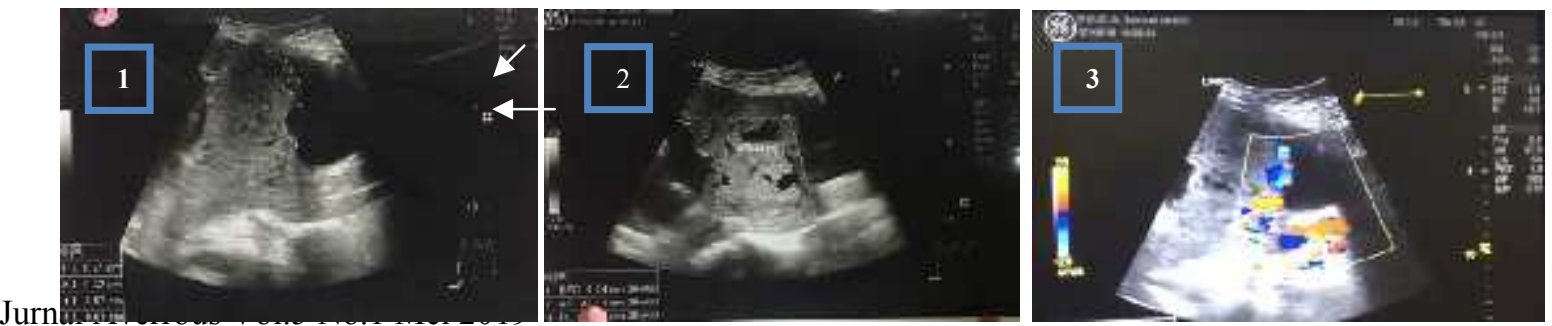
Diagnosis of this patient is G3P2 36-37 wga singleton live transvers lie head on left side dorso superior, previous caesarean section 2 time (interval delivery time 13 years), placenta previa totalis, placenta percrete. In this patient, elective conservative surgical management is planned, namely cesarean section to cesarean hysterectomy involving multidisciplinary science on August $8^{\text {th }} 2018$ performed cesarean section with a corporal incision birth of female baby with birth weight of $3500 \mathrm{~g}$, Apgar score $8 / 9$, body length of $50 \mathrm{~cm}$, balard score according to 38-40 weeks, the impression of term neonate appropriate for gestational age.
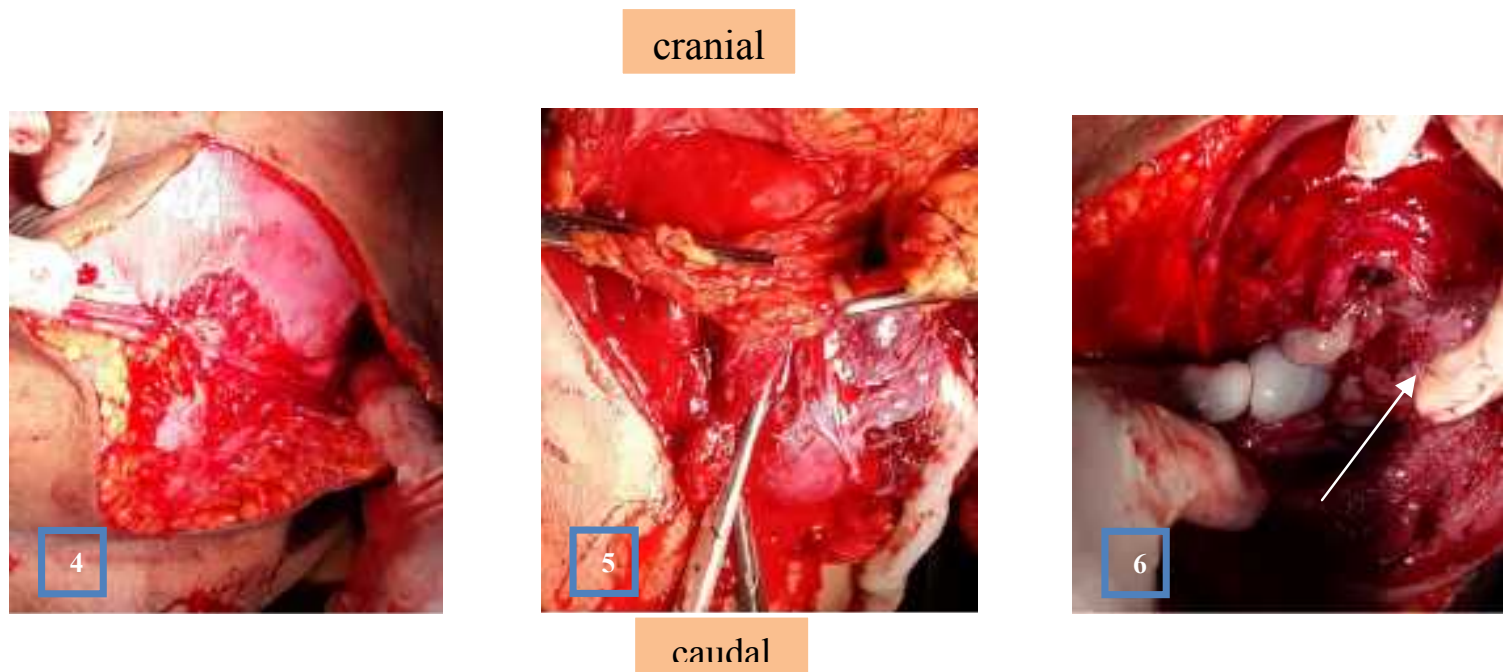

Figure4. Severe adhesion between peritoneum with lower uterine segmen

Figure5. Placenta adhesive was invased until uterine serosa

Figure 6. Fetal cord and placenta invasion

Source :Photointra operativemedical recordZainoelAbidin Hospital Banda Aceh, MR 1181009

Intra operative shows that the placenta implants in the anterior corpus extends to cover of the ostium uteri internum and there is obtained the placenta invades to the uterine serous layer and there is no invasion from the placenta to the vesica urinaria or other intra-abdominal organs. So it was decided to do a hysterectomy without giving birth to the placenta first. But in this case there was no ligation of the hypogastric artery or tourniquet on the lower of the uterus segmen.
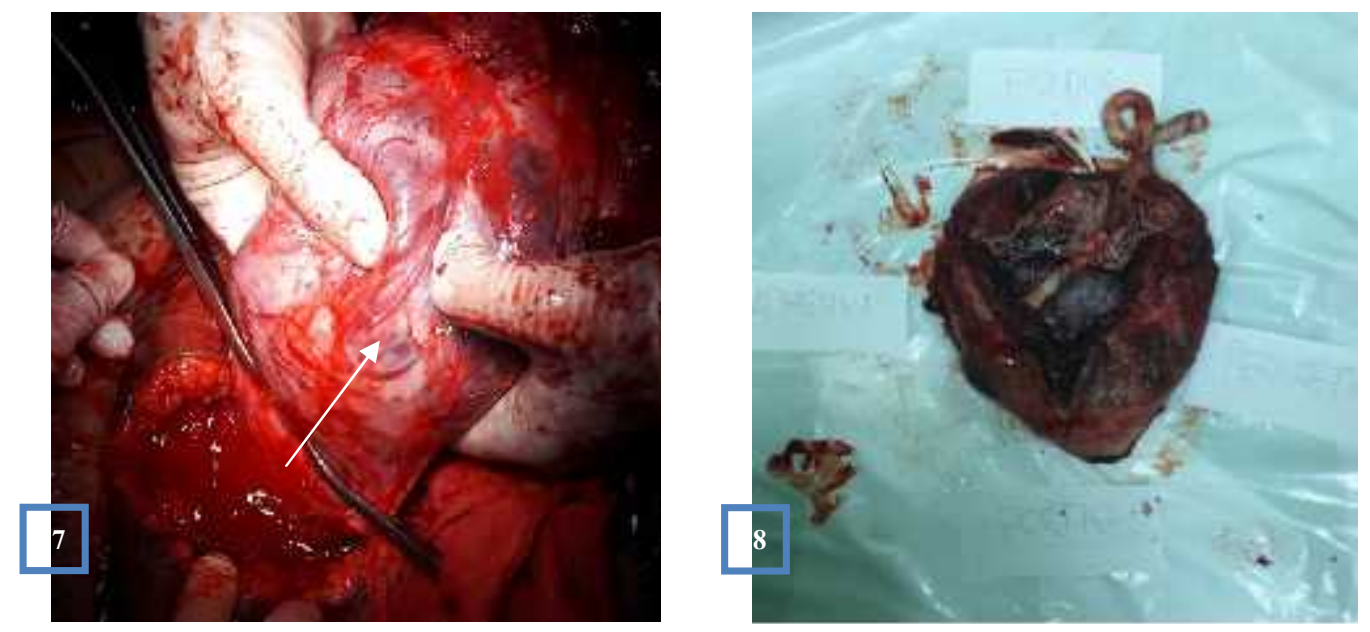


\section{DISCUSSION}

Placenta accreta spectrum should be suspected in women with placenta previa, especially those implanted in the anterior corpus, and a history of cesarean or other uterine surgeries[3]. In these patients fetal ultrasound was found transvers lie with placenta previa totalis and anterior implanted placenta, also obtained lacunae and bridging vessels with doppler examination (PAI score 8) according to $83 \%$ probability. Based on anamnesis results, physical examination and other investigations can be made diagnosed in these patients with G3P2A0 36-37 wga transvers lie head at the left side dorso superior, previous caesarean section 2 time, placenta previa totalis, placenta accreta. This patient management plan is surgical conservative management with corporal incisions away from placental implantation, giving birth to a baby without a placenta, followed by a hysterectomy, has been shown to reduce the risk of bleeding and need for blood transfusion.

The discovery of placenta accreta spectrum earlier when antenatal care, planning delivery is better than multidisciplinary science there is fetomaternal division, gynecology oncologist, anesthesiologist, thorac\& cardiovascular surgeon, radiology intervention, intensivis-obstetrics intensive care, urologist and neonatology can determined the successfully of handling cases of placenta accreta spectrum so as to reduced maternal, fetal morbidity and mortality ${ }^{[17]}$.

The pathogenesis of morbidly placenta accreta spectrum includes defects in the fibrinoid layer of nitabuch or in the decidua basalis caused by a variety of insults like excessive curettage, infection or previous uterine surgery ${ }^{[29,30]}$. Pathophysiology also includes excessive trophoblastic invasion ${ }^{[27,29]}$. Placenta previa is also a risk factor ${ }^{[6]}$. In our patient, placenta previa and cesarean history 2 time is risk factor was observed, there might have been excessive trophoblastic invasion. The increased rate of placenta percreta is due to the increased cesarean section rate ${ }^{[28,29]}$.

\section{PRENATAL SCREENING FOR PLACENTA ACCRETA SPECTRUM DISORDERS | Clinical screening |}

Several risk factors for placenta accreta spectrum disorders have been identified. These include advanced maternal age, multiparity, previous uterine surgery including curettage, assisted reproductive techniques, and previous cesarean section ${ }^{[14]}$. The most commonly described risk factor is the combination of previous cesarean delivery and placenta previa $^{[15]}$. This combination also poses other problems, including increased risk of prenatal bleeding, access to the fetus for delivery, and the relatively poor contractility of the lower segment leading to greater postpartum blood loss ${ }^{[16]}$.

The prevalence of placenta accreta spectrum disorders in the general population of pregnant women is around 1.7 per 10000 pregnancies ${ }^{[14,15]}$. However, the incidence of placenta previaaccreta is $4.1 \%$ in women with one prior cesarean delivery and $13.3 \%$ in women with two or more previous cesareans, and continues to rise with the number of prior cesareans ${ }^{[14]}$.Thus, focusing the screening of placenta accreta spectrum disorders on this group is more productive in terms of diagnostic yield. All women found to have an anterior low-lying (placental edge $<2 \mathrm{~cm}$ from the internal cervical os after 16 weeks of gestation) or placenta previa should be asked if they have had a previous cesarean delivery during prenatal consultations and, if they do, they should be referred to a center with expertise in the prenatal diagnosis of placenta accreta spectrumdisorders ${ }^{[14,15]}$.

The management of placenta accreta spectrumincluded placenta accreta, increta, and 
percretawill be discussed here and is essentially the same, except when a percreta extends to extrauterine tissue. Unless otherwise noted, the following discussion of management of placenta accreta spectrum applies to all depths of placental invasion. The clinical features and diagnosis of PAS are reviewed separately ${ }^{[2]}$. All patients with suspected placenta accrete advantageous for low and middle income countries where expensive additional treatments such as interventional radiology may not be available ${ }^{[40]}$.

spectrum should be counseled about the diagnosis and potential sequelae (eg, hemorrhage, blood transfusion, cesarean hysterectomy, maternal intensive care unit admission). Consultation with a maternalfetal medicine specialist is desirable, and transfer to a center of excellence for placenta accreta is strongly advised. For patients with placenta previaaccreta, prenatal care follows typical guidelines for management of placenta previa. Nonstress tests and/or biophysical profile scores are not performed routinely, but are used in pregnancies that have standard indications for these tests (fetal growth restriction, preeclampsia, oligohydramnios, and soon) ${ }^{[20]}$.

A significant proportion of cases of placenta previa are associated with placenta accreta spectrum disorders, particularly if the uterus is scarred and the placenta is anterior and/or covering the cervix. Even if no villous tissue is invading the uterine myometrium, access to the fetus is complicated by the position of the underlying placenta, the lower uterine segment adjacent to the placenta is highly vascularized, and major hemorrhage can still occur. It would be incorrect to believe that major morbidity should be expected only if prenatal diagnosis of placenta accreta spectrum disorders has been made ${ }^{[14]}$.

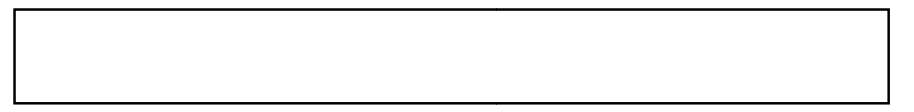

Algoritma Management PlasentaAcreta Spectrum

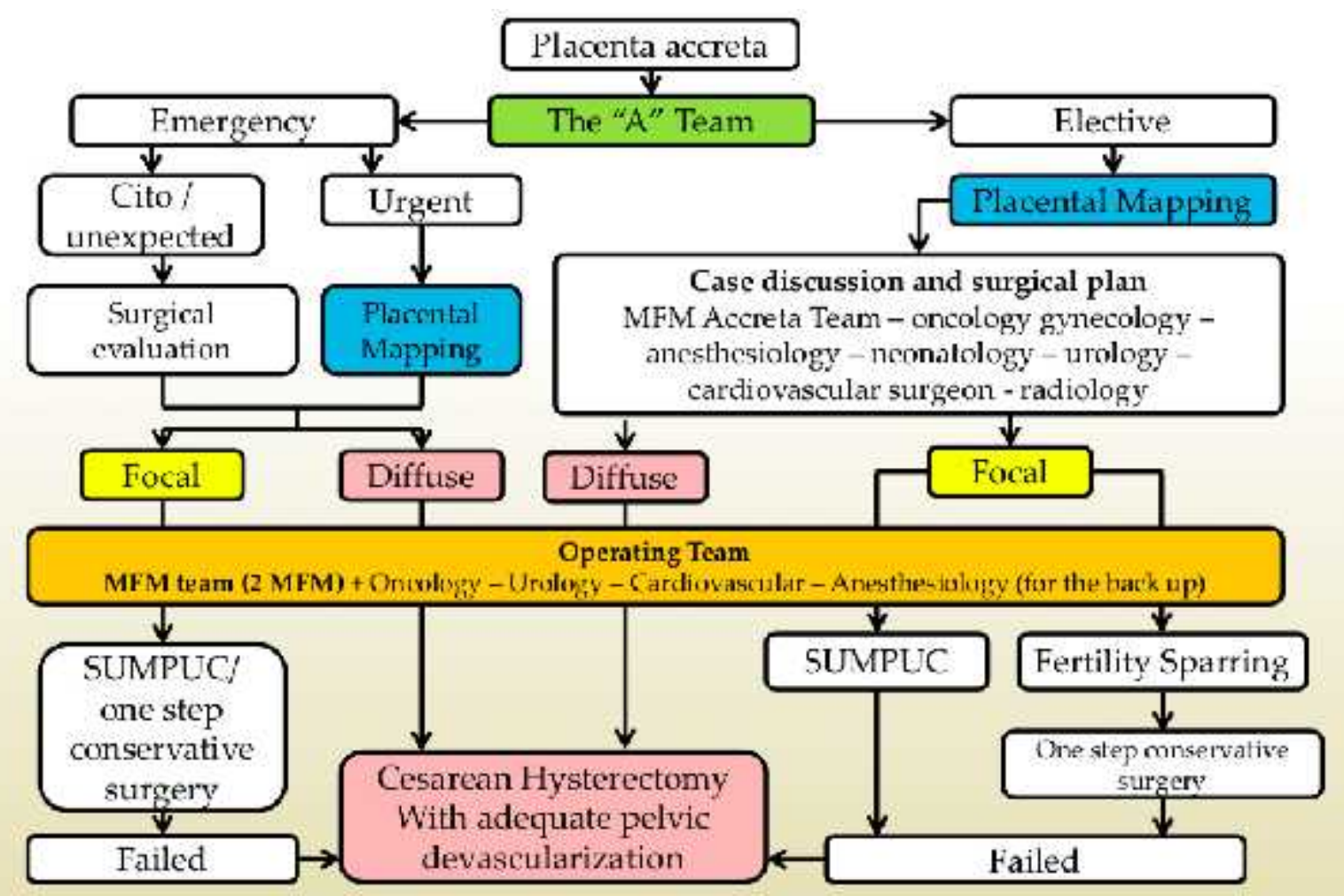

Source: The A Team, maternal fetal medicine div. Obstetric \& Gynecology department Dr. Soetomo General Hospital, Universitas Airlangga, Surabaya 2018

PROCEDURE

ALTERNATIVE CONSERVATIVE SURGICAL PROCEDURES 


\section{One-step conservative surgery}

This surgical procedure has been described primarily by one author ${ }^{[38]}$.It consists of resecting the invasive accreta area (partial myometrial resection) followed by immediate uterine reconstruction and bladder reinforcement ${ }^{[39]}$. This strategy aims to combine the advantages of both the "leaving in situ approach" of preserving the uterus and cesarean hysterectomy with minimal risk of secondary bleeding or infection. The main steps in this uterine sparing technique can be performed via a modified Pfannenstiel or midline incision (Box 1).It is

\begin{tabular}{l} 
Box 1 One step conservative surgery approach \\
for placenta accreta spectrum (PAS) disorder. \\
\hline $\begin{array}{l}\text { Vascular disconnection of newly-formed (feeder) vessels } \\
\text { and the separation of invaded uterine tissues from } \\
\text { invaded vesical tissues. }\end{array}$ \\
\hline Upper-segmental hysterotomy and delivery of the fetus. \\
\hline Resection of all invaded myometrial tissue and the entire \\
\hline $\begin{array}{l}\text { placenta in one piece with previous local vascular } \\
\text { control. }\end{array}$ \\
\hline Surgical procedures for hemostasis. \\
\hline Myometrial reconstruction in two planes. \\
\hline Bladder repair if necessary. \\
\hline
\end{tabular}

\begin{tabular}{l} 
Box 2 Stepwise surgical approach for placenta accreta \\
spectrum (PAS) disorders. \\
$\begin{array}{l}\text { Combined early intravenous uterotonics just before delivery of } \\
\text { the fetus. }\end{array}$ \\
\hline $\begin{array}{l}\text { Transverse "high" uterine incision at the upper border of the } \\
\text { placenta without cutting through the placenta. }\end{array}$ \\
\hline Fetal delivery. \\
\hline $\begin{array}{l}\text { The uterus is exteriorized and compressed against the } \\
\text { symphysis pubis by assistant (transient bilateral kink of } \\
\text { uterine arteries). }\end{array}$ \\
\hline Bilateral anterior division of internal iliac artery ligations. \\
\hline Placental extraction (delayed after pelvic devascularization). \\
\hline $\begin{array}{l}\text { Proper identification of lower uterine segment by index and } \\
\text { ring fingers after identification of internal cervical os by } \\
\text { middle finger of left hand. }\end{array}$ \\
\hline Repair of uterine incision.
\end{tabular}

Box 1 and 2 one step and stepwise conservative surgery for Placenta accrete spectrum

Source: FIGO consensus guidelines on placenta accreta spectrum disorders: Conservative management,Int J Gynecology \&Obstetry2018; 140: 291-298, doi:10.1002/ijgo.12410

In a cohort study of 68 women presenting with placental invasion of the adjacent organs including invasion of the posterior upper bladder section $(n=46$; group 1$)$ or of the posterior lower vesical section ( $\mathrm{n}=22$; group 2), uterine preservation was achieved in 44 out of 46 $(95.7 \%)$ and 6 out of $22(27.3 \%)$ cases, respectively[3].The indications for the 18 hysterectomies were segmental circumferential rupture greater than $50 \% \quad(n=13)$, coagulopathy $(n=2)$, infection $(n=1)$, and uncontrolled hemodynamic instability $(n=2)$. Among the 50 women with uterine preservation, follow-up was available for 42 patients. A normal menstrual cycle returned between 3 and 16 months. Ten women had another uneventful pregnancy and delivery with no recurrence of placenta accrete spectrum disorders ${ }^{[40]}$.

\section{| The Triple-P procedure}

A novel uterine-sparing procedure for placenta accrete spectrum disorders called the "Triple$\mathrm{P}$ procedure" was recently proposed ${ }^{[30,31]}$.The aim of this procedure is to avoid incising through the vascular placental venous sinuses, and to excise the myometrium with PAS disorder tissue and to reconstitute the uterine defect. The main steps of this procedure include: (1) perioperative placental ultrasound localization of the superior edge of the placenta; (2) pelvic devascularization involving preoperative placement of intraarterial balloon catheters (anterior division of the internal iliac arteries); and (3) no attempt to remove the entire placenta with large myometrial excision and uterine repair. If the posterior wall of the bladder is involved, the placental tissue invading the bladder is left in situ to avoid cystotomy ${ }^{[15]}$.

A comparison of two periods (i.e. before implementation of the Triple-P procedure $(n=11)$ and after $(n=19))$ showed no difference in the estimated mean blood loss and rate of 
transfusion; however, the rates of postpartum hemorrhage and hysterectomy were lower in the Triple-P procedure group ${ }^{[30]}$.Larger studies are needed to demonstrate the safety and efficacy of this technique ${ }^{[15]}$.

\section{| Cesarean Hysterectomy |}

Preoperative ureteral stents may be placed, although they are of unproven efficacy. We make a vertical skin incision or a Cherney incision and inspect the pelvis for signs of percreta and the location of any collateral blood supply. An intraoperative ultrasound examination may be done to map the placental edge and determine the best position for the hysterotomy incision. We make a vertical hysterotomy at least two fingerbreadths above the placental edge; leaving a myometrial margin between the placenta and incision helps to prevent disruption of the placenta during opening or closing of the uterus ${ }^{[14]}$.

After delivery of the infant, the cord is cut, the uterine incision is rapidly closed to decrease blood loss, and hysterectomy is performed. We avoid internal iliac (hypogastric) artery ligation because it is time consuming, operator dependent, ineffective (without hysterectomy) for controlling pelvic hemorrhage in up to 60 percent of cases ${ }^{[32-33]}$, and precludes use of selective pelvic angiography and embolization if needed subsequently ${ }^{[15]}$.

Management of placenta percreta with bladder invasion, placenta percreta with bladder invasion may require partial cystectomy. In one review of 54 cases of placenta percreta invading the bladder, partial cystectomy was performed in 24 of the 54 patients $^{[32]}$. Ideally, aurogynecologist, urologist, or gynecologic oncologist should be consulted when the bladder is involved. Cystoscopy or intentional cystotomy at surgery is often helpful for assessing the degree of bladder, and possible ureteral, involvement ${ }^{[33]}$.

\section{CONSERVATIVE PROCEDURES OF PLACENTA ACCRETA}

Uterine conservation may be considered when the patient very much wants to preserve her fertility. She should be counseled extensively regarding the risks of hemorrhage, infection, possible need for intra or post operative life saving hysterectomy, and even death, as well as suboptimal outcomes (including recurrence or hemorrhage) in future pregnancies. Uterine conservation is also considered when hysterectomy is thought to have an unacceptably high risk of hemorrhage or injury to other organs, which may be mitigated by leaving the placenta in $\operatorname{situ}^{[18,22]}$.

Uterine conservation with the placenta left in situ - In this approach, the placenta is left in situafter delivery of the newborn and ligation of the cord at its placental insertion site. The hysterotomy is closed in the standard way; uterotonic drugs, compression sutures, balloon tamponade, uterine artery embolization, and/or uterine artery ligation are used, as needed, to manage postpartum hemorrhage ${ }^{[34]}$.

Adjunctive therapy with methotrexate therapy has been tried, with no convincing evidence that it improves any outcome in these cases, and clear evidence of drug related harms (pancytopenia, nephrotoxicity);it should not be used. Delayed hysteroscopic resection of placental remnants has been used successfully to expedite resolution of the placenta or treat delayed bleeding and/or pelvic pain, but experience is limited ${ }^{[35-36]}$.

The immediate complications, as well as long term outcomes, of women who undergo uterine conservation indicate that this approach should be attempted only rarely, in fully informed patients, or as part of approved clinical trials. This is consistent with a Committee Opinion of the American College of Obstetricians and Gynecologists ${ }^{[33]}$. The prolonged course and significant risks of uterine conservation with the placenta left in situ were illustrated by a systematic review of 10 cohort studies and 50 case series or case reports describing 434 patients with placenta accreta, increta, or percreta managed conservatively (expectant 
management, uterine artery embolization, methotrexate therapy, hemostatic sutures, arterial ligation, balloon tamponade) ${ }^{[37]}$.

This approach is based on the following evidence-based clinical concepts ${ }^{[15]}$ : (1)Cesarean hysterectomy is considered the gold standard treatment for invasive accreta but it remains associated with high rates $(40 \%-50 \%)$ of severe maternal morbidity and, in cases of placenta percreta, the mortality rates can be as high as $7 \%$ owing to damage to pelvic organs and vasculature. (2) The extirpative method is associated with severe maternal morbidity because it leaves, within the myometrium, placental tissues connected to large feeding vessels, which are responsible for uncontrolled massive obstetric hemorrhage ${ }^{[40]}$.

By leaving a placenta accreta in situ after the delivery of the fetus, one can expect a progressive decrease in blood circulation within the uterus, parametrium, and the placenta. This will result in secondary necrosis of the villous tissue and theoretically the placenta should progressively detach itself from the uterus and the percreta villi from the adjacent pelvic organs. Two separate surveys from the Society for Maternal Fetal Medicine $(\mathrm{SMFM})^{[14,15]}$ reported that $14.9 \%$ of practitioners would attempt to leave the placenta in situ in a hemodynamically stable patient and $32 \%$ had attempted conservative expectant management for placenta accrete spectrum disorders. In an older survey on the preferences for surgical versus conservative therapy in cases of placenta percreta, it was found that when adjacent pelvic organs such as the bladder and bowel are involved, the majority of members of the Society of Perinatal Obstetricians, with and without recent experience in the management of placenta accrete spectrum disorders, opt for conservative management $(69 \%$ and $70 \%$, respectively) compared with $31 \%$ when the accreta villous tissue is confined to the uterus (percreta or increta) ${ }^{[37]}$.

\section{CONCLUSION}

This patients reported with management of conservative surgery have a succesfullywith corporal incisions away from placental implantation, giving birth to a baby without a placenta, followed by a hysterectomy, has been shown to reduce the risk of bleeding and need for blood transfusion.

Preoperative patient counseling should included discussion of the potential need for hysterectomy, the risks of profuse hemorrhage, and possible maternal death.The recommended management of suspected placenta accrete spectrum is planned preterm cesarean hysterectomy with the placenta left in situ because removal of the placenta is associated with significant hemorrhagic morbidity.

\section{REFERENCES}

1. American College of Obstetricians and Gynecologists. ACOG Committee opinion \#529. Placenta accreta. ObstetGynecol 2012; 120:207.

2. Publications Committee, Society for Maternal-Fetal Medicine, Belfort MA. Placenta accreta. Am J ObstetGynecol 2010; 203:430.

3. Kaser DJ, Melamed A, Bormann CL, et al. Cryopreserved embryo transfer is an independent risk factor for placenta accreta. FertilSteril 2015; 103:1176.

4. Fitzpatrick KE, Sellers S, Spark $P$, et al. Incidence and risk factors for placenta accreta/increta/percreta in the UK: a national case-control study. PLoS One 2012; 7:e52893.

5. Miller DA, Chollet JA, Goodwin TM. Clinical risk factors for placenta previa-placenta accreta. Am J ObstetGynecol 1997; 177:210.

6. Wu S, Kocherginsky M, Hibbard JU. Abnormal placentation: twenty-year analysis. Am J ObstetGynecol 2005; 192:1458.

7. Read JA, Cotton DB, Miller FC. Placenta accrete: changing clinical aspects and outcome. ObstetGynecol 1980; 56:31 
8. Mehrabadi A, Hutcheon JA, Liu S, et al. Contribution of placenta accreta to the incidence of postpartum hemorrhage and severe postpartum hemorrhage. ObstetGynecol $2015 ; 125: 814$.

9. The A Team, maternal fetal medicine div. Obstetric \& Gynecology department Dr. Soetomo General Hospital, Universitas Airlangga, Surabaya 2018

10. SivasankarChitra, Perioperative management of undiagnosed placenta percreta: case report and management strategies, International Journal of Women's Health, 2012, USA.

11. Eliza and Alfred, Prenatal Diagnosis of Placenta Accreta, The American Institute of Ultrasound in Medicine, 2013, USA.

12. Tantbirojn P, Crum CP, Parast MM. Pathophysiology of placenta creta: the role of decidua and extravilloustrophoblast. Placenta 2008; 29:639.

13. Khong TY. The pathology of placenta accreta, a worldwide epidemic. J ClinPathol 2008; 61:1243.

14. Jauniaux E, Jurkovic D. Placenta accreta: pathogenesis of a 20th century iatrogenic uterine disease. Placenta 2012; 33:244.

15. Jauniaux E, Collins S, Burton GJ. Placenta accreta spectrum: pathophysiology and evidence-based anatomy for prenatal ultrasound imaging. Am J ObstetGynecol 2018; 218:75.Int $J \quad$ GynecolObstet2018; 140: 291-298 wileyonlinelibrary.com/journal/ijgo (C) 2018 International Federation of Gynecology and Obstetrics

16. Ben-Nagi J, Walker A, Jurkovic D, et al. Effect of cesarean delivery on the endometrium. Int J GynaecolObstet 2009; 106:30.

17. Eller AG, Bennett MA, Sharshiner M, et al. Maternal morbidity in cases of placenta accreta managed by a multidisciplinary care team compared with standard obstetric care. ObstetGynecol 2011; 117:331.

18. Shamshirsaz AA, Fox KA, Salmanian B, et al. Maternal morbidity in patients with morbidly adherent placenta treated with and without a standardized multidisciplinary approach. Am J ObstetGynecol 2015; 212:218.e1.

19. Pri-Paz S, Fuchs KM, Gaddipati S, et al. Comparison between emergent and elective delivery in women with placenta accreta. J Matern Fetal Neonatal Med 2013; 26:1007.

20. Society for Maternal-Fetal Medicine (SMFM). Electronic address: pubs@smfm.org, Gyamfi-Bannerman C. Society for Maternal-Fetal Medicine (SMFM) Consult Series \#44: Management of bleeding in the late preterm period. Am J ObstetGynecol 2018; 218:B2.

21. Shamshirsaz AA, Fox KA, Erfani H, et al. Outcomes of Planned Compared With Urgent Deliveries Using a Multidisciplinary Team Approach for Morbidly Adherent Placenta. ObstetGynecol 2018; 131:234.

22. Bowman ZS, Manuck TA, Eller AG, et al. Risk factors for unscheduled delivery in patients with placenta accreta. Am J ObstetGynecol 2014; 210:241.e1.

23. Eller AG, Porter TF, Soisson P, Silver RM. Optimal management strategies for placenta accreta. BJOG 2009; 116:648.

24. Warshak CR, Ramos GA, Eskander R, et al. Effect of predelivery diagnosis in 99 consecutive cases of placenta accreta. ObstetGynecol 2010; 115:65.

25. Oyelese Y, Smulian JC. Placenta previa, placenta accreta, and vasa previa. ObstetGynecol 2006; 107:927.

26. Wong HS, Hutton J, Zuccollo J, et al. The maternal outcome in placenta accreta: the significance of antenatal diagnosis and non-separation of placenta at delivery. $\mathrm{N} \mathrm{Z} \mathrm{Med} \mathrm{J}$ 2008; $121: 30$.

27. Khong TY (2008) The pathology of placenta accreta, a worldwide epidemic. J ClinPathol 61: 1243-1246.

28. Tantbirojn P, Crum CP, Parast MM (2008) Pathophysiology of placenta creta: the role of decidua and extravilloustrophoblast. Placenta 29: 639-645.

29. Thia EW, Lee SL, Tan HK, Tan LK (2007) Ultrasonographical features of morbidly- 
adherent placentas. Singapore Med J 48: 799-802.

30. TeixidorViñas M, Belli AM, Arulkumaran S, Chandraharan E. Prevention of postpartum hemorrhage and hysterectomy in patients with morbidly adherent placenta: A cohort study comparing outcomes before and after introduction of the Triple-P procedure. Ultrasound Obstet Gynecol. 2015;46:350-355.

31. Chandraharan E, Rao S, Belli AM, Arulkumaran S. The Triple-P procedure as a conservative surgical alternative to peripartumhys- terectomy for placenta percreta. Int $J$ Gynecol Obstet. 2012;117: 191-194.

32. Unal O, Kars B, Buyukbayrak EE, et al. The effectiveness of bilateral hypogastric artery ligation for obstetric hemorrhage in three different underlying conditions and its impact on future fertility. J Matern Fetal Neonatal Med 2011; 24:1273.

33. Fox KA, Shamshirsaz AA, Carusi D, et al. Conservative management of morbidly adherent placenta: expert review. Am J ObstetGynecol 2015; 213:755.

34. Legendre G, Zoulovits FJ, Kinn J, et al. Conservative management of placenta accreta: hysteroscopic resection of retained tissues. J Minim Invasive Gynecol 2014; 21:910.

35. Hequet D, Morel O, Soyer P, et al. Delayed hysteroscopic resection of retained tissues and uterine conservation after conservative treatment for placenta accreta. Aust N Z J ObstetGynaecol 2013; 53:580.

36. Rein DT, Schmidt T, Hess AP, et al. Hysteroscopic management of residual trophoblastic tissue is superior to ultrasound-guided curettage. J Minim Invasive Gynecol 2011; 18:774.

37. Steins Bisschop CN, Schaap TP, Vogelvang TE, Scholten PC. Invasive placentation and uterus preserving treatment modalities: a systematic review. Arch GynecolObstet 2011; 284:491.

38. Palacios-Jaraquemada JM, Pesaresi M, Nassif JC, Hermosid S. Anterior placenta percreta: Surgical approach, hemostasis and uterine repair. ActaObstetGynecol Scand. 2004;83:738-744.

39. Palacios-Jaraquemada JM. Diagnosis and management of placenta accreta. Best Pract Res ClinObstet Gynecol. 2008;22:1133-1148. 52.

40. Palacios-Jaraquemada JM. Placental Adhesive Disorders. Berlin/Boston: Walter de Gruyter; 2012. 